\title{
Biochemical Estimation of Metabolites from Medicinally Important Plant Tecomella undulata (sm.) Seem
}

\author{
Manisha Patel ${ }^{1}$, R. S. Patel ${ }^{2}$ \\ ${ }^{1}$ J.J.T.University Jhunjhunu, Rajasthan, India \\ ${ }^{2}$ KKSJ Maninagar Science College, Ahmedabad, India
}

\begin{abstract}
Tecomella undulata is the richest source of phytocontituents and have been used frequently in folk medicine. The results for total phenolic, total flavonoid content, total alkaloid content, total tannin content is studied in various plant extracts of leaves and stem. The highest amount of total phenolic content $(31.04 \mathrm{mg} / \mathrm{g})$, total flavanoids content $(32.23 \mathrm{mg} / \mathrm{g})$, total tannin content (14.27mg/g), total alkaloids content $(14.38 \mathrm{mg} / \mathrm{g})$ was observed in leaves and chlorophyll $(12.68 \mathrm{mg} / \mathrm{g})$ in leaves. The powerful biological activities as exhibited by plant phenolics and flavonoids posed the need of determining their contents in Tecomella undulata leaves and stem. The contents were determined by spectrophotometric assays by measuring the absorbance at different wavelengths. Total phenolic content were estimated by the Folin-Ciocalteu colorimetric method whereas the total flavonoid content was estimated by aluminium chloride colourimetric method. The results clearly indicate that $T$. undulata is a rich source of phenolics and flavonoids the basis of its traditional use in different systems of medicines.
\end{abstract}

Keywords: Tecomella undulata, total phenolic, total flavonoid content, total alkaloid content, total tannin content, plant extracts of leaves and stem

\section{Introduction}

The plants Tecomella undulata are widely used for the treatment of a broad-standing human ailments since extensive times. The plant is known, a number of activities, such as antibacterial, cardiotonic and chloretic, mild relaxant, hepatoprotective, anticancer activity etc. In ayurveda Tecomella undulata is used for the different diseases, skin diseases, cancer, diabetes, jaundice, gonorrhoea, leucoderma enlargement of spleen, central nerves system, liver diseases, urinary disorders and swellings. Seeds are used against abscess and flowers are used for Hepatitis. Leaves shows significant antimicrobial activity and is potent to anti-human immunodeficiency virus due to the presence of oleanolic acid and ursolic acid (Azam, M. M., 2000). Today, the collection of medicinal plants in nature as a raw material widely used in pharmaceutical industry as well as the various medical the inevitable cultural practices. It has great ayurvedic properties and also used in preparation of ayurvedic drug wiz. rohitakarista, rohitakadhya churna and rohitaka ghrita. The most important bioactive substances of plants are alkaloids, flavonoids, glycosides, saponins, tannins, phenolic compounds, quinones, anthroquinones, sterols which create certain physiological action on human body and assist defense activity against microorganisms, insects and herbivores and play diverse role in plant for the discovery of therapeutic agents.

\section{Material and Method}

For the quantitative estimation of secondary metabolites different protocols were used. Leaves and stem of the mature plant were collected, washed with distilled water, shade dried and powdered. The powder was used for analysis of total phenolic, total flavonoid content, total alkaloid content and total tannin content of the selected plant species.

\section{Determination of total phenolic content}

Total phenolic content was determined by Folin -ciocalteu reagent method. Take $1 \mathrm{ml}$ of different plant extracts (leaves and stem) of Tecomella undulata. Add $0.5 \mathrm{ml} 1 \mathrm{~N}$ Folin ciocalteu reagent. Allow standing for $10 \mathrm{~min} .4 \mathrm{ml} \mathrm{Na} \mathrm{CO}_{3}$ solution added. The reaction mixtures were incubated for 30 min. The total phenolic content was measure at $750 \mathrm{~nm}$. Gallic acid solutions used as standard and was expressed in terms of $\mathrm{mg} / \mathrm{g}$ phenolic content.

\section{Determination of total alkaloids content}

Take $1 \mathrm{ml}$ different plant extracts Tecomella undulata. Add $5 \mathrm{ml}$ phosphate Buffer. Then add $5 \mathrm{ml}$ of bromocresol green solution. The mixture was shaken with $4 \mathrm{ml}$ chloroform. After that the reaction mixtures is collected in volumetric flask $(10 \mathrm{ml})$ and make final volume $10 \mathrm{ml}$ with chloroform. The total alkaloid content was measure at $470 \mathrm{~nm}$. Atropine solutions used as standard and expressed in terms of $\mathrm{mg} / \mathrm{g}$ alkaloid content.

\section{Total tannin content determination}

Folin - Ciocalteu method was used for the determination of tannins using tannic acid as a standard. Take $1 \mathrm{ml}$ of plant extract is collected in volumetric flask $(10 \mathrm{ml}) .4 .0 \mathrm{ml} \mathrm{D} / \mathrm{W}$ was added. Then add $0.4 \mathrm{ml}$ of $1 \mathrm{~N}$ Folin- ciocalteu reagent. Then add $2 \mathrm{ml}$ of saturated $\mathrm{Na}_{2} \mathrm{CO}_{3}$ solution. Make final volume $10 \mathrm{ml}$ with distilled water. Measured OD against the blank at $700 \mathrm{~nm}$ with spectrophotometer. The results were expressed in $\mathrm{mg} / \mathrm{g}$ of plant extract.

\section{Total flavanoid content determination}

Aluminium chloride method was used for determination of total flavanoids content. Quercetin was used as standard for 


\section{International Journal of Science and Research (IJSR) \\ ISSN (Online): 2319-7064}

Index Copernicus Value (2013): 6.14 | Impact Factor (2015): 6.391

determination of total flavonoids content. $1 \mathrm{ml}$ of various plant extracts were collected in volumetric flask (10ml). 4 $\mathrm{ml}$ water was added and allows standing for $5 \mathrm{~min}$. Then add $0.5 \mathrm{ml} 10 \% \mathrm{AlCl}_{3} .0 .5 \mathrm{ml}$ of $5 \% \mathrm{CH}_{3} \mathrm{COONa}$ (NaOAc) was added and allows standing for $5 \mathrm{~min}$. Add $2 \mathrm{ml}$ of $1 \mathrm{M} \mathrm{NaOH}$ in test solution and make $10 \mathrm{ml}$ final volume with $\mathrm{D} / \mathrm{W}$. Measured the OD at $415 \mathrm{~nm}$ against a blank with an UV spectrophotometer. The content was expressed in $\mathrm{mg} / \mathrm{g}$ dry weight of extracts.

\section{Results and Discussion}

The present work indicates the plant T. undulata is the richest source of phenolic, tannin and flavonoid content. The results for total phenolic, total flavonoid content, total alkaloid content and total tannin content is studied in various plant extracts of leaves and stem are presented in the graph. The leaf of plant Tecomella undulata contains higher total phenolic content, total flavanoid content, total alkaloids content and total tannin content then stem exception of ethyl acetate stem extracts show higher phenolic content than leaves extracts. The highest value was $31.04 \mathrm{mg} / \mathrm{g}$ recorded in petroleum ether leaves extracts followed by $28.66 \mathrm{mg} / \mathrm{g}$ in methanol $21.46 \mathrm{mg} / \mathrm{g}$ in chloroform, $16.77 \mathrm{mg} / \mathrm{g}$ in acetone, $12.44 \mathrm{mg} / \mathrm{g}$ in ethyl acetate and 6.25 in water (graph 2). The high value was $23.28 \mathrm{mg} / \mathrm{g}$ recorded in petroleum ether stem extracts followed by $20.42 \mathrm{mg} / \mathrm{g}$ in methanol $18.86 \mathrm{mg} / \mathrm{g}$ in chloroform, $14.38 \mathrm{mg} / \mathrm{g}$ in acetone and $15.6 \mathrm{mg} / \mathrm{g}$ in ethyl acetate. No phenolic content was observed in water stem extracts (graph 2).

The highest flavanoid content was $32.23 \mathrm{mg} / \mathrm{g}$ recorded in methanol leaves extracts followed by $24.36 \mathrm{mg} / \mathrm{g}$ in chloroform and $23.94 \mathrm{mg} / \mathrm{g}$ was recorded in methanol stem extracts. No flavanoid content was observed in water stem extracts. The results will be shown in and represented in graph 4 . The high alkaloid content was $14.38 \mathrm{mg} / \mathrm{g}$ recorded in methanol leaves extracts followed by $11.28 \mathrm{mg} / \mathrm{g}$ in petroleum ether. No alkaloids present in $\mathrm{CH}$, EA and water extract (graph 6). The highest tannin content was $18.5 \mathrm{mg} / \mathrm{g}$ recorded in petroleum ether stem extracts and $13.25 \mathrm{mg} / \mathrm{g}$ recorded in petroleum ether leaves extracts (graph 8). No tannin content was observed in acetone leaf extracts.

\section{Conclusion}

The present study revealed that plant Tecomella undulata contains high content of phenolic compound, flavanoids, alkaloids contribute to the antioxidant activity and is considered to be great potential source of antimicrobial principles. For this reason, it is resistant to bacteria and fungal attacks.

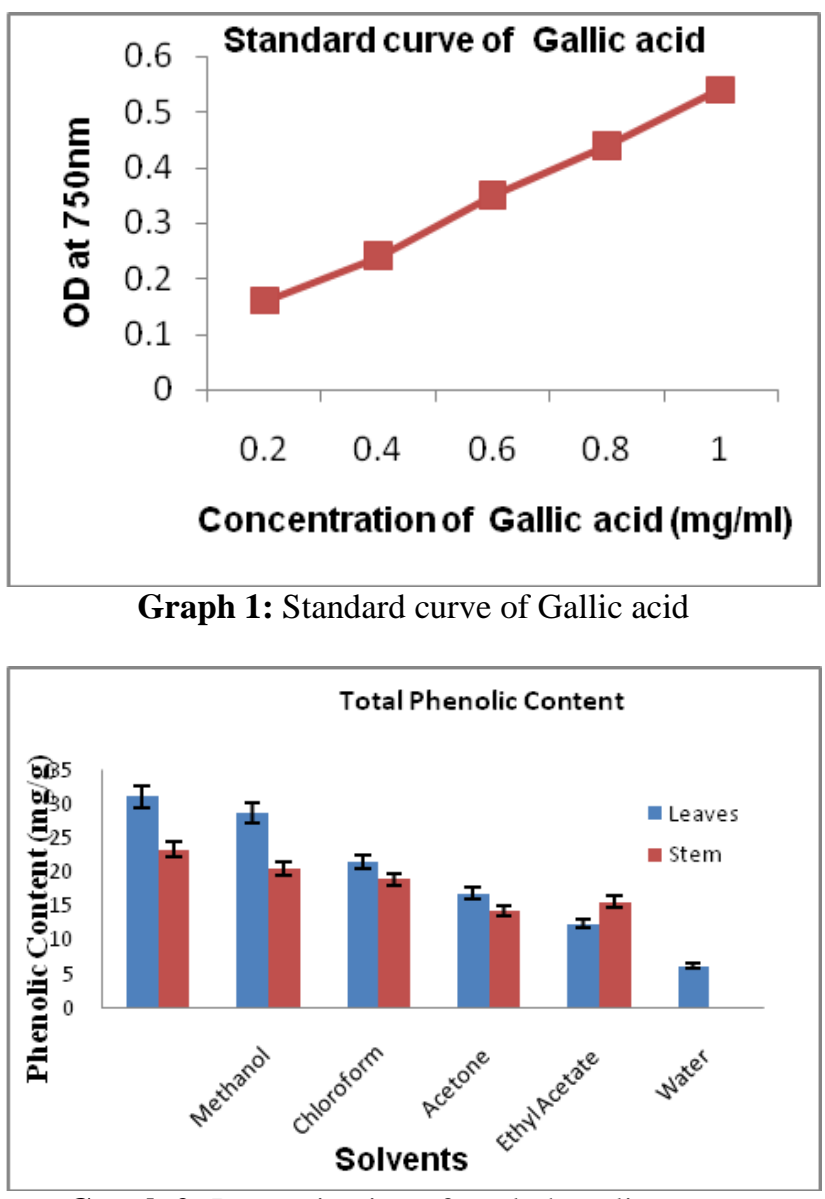

Graph 2: Determination of total phenolic content

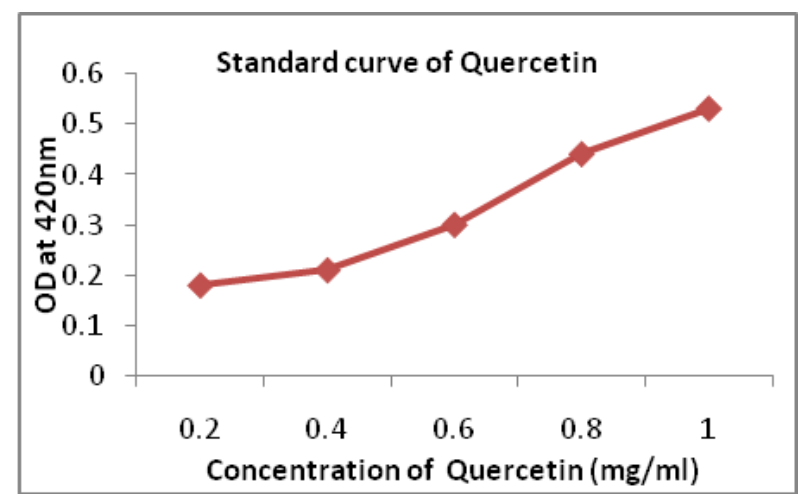

Graph 3: Standard curve of Quercetin

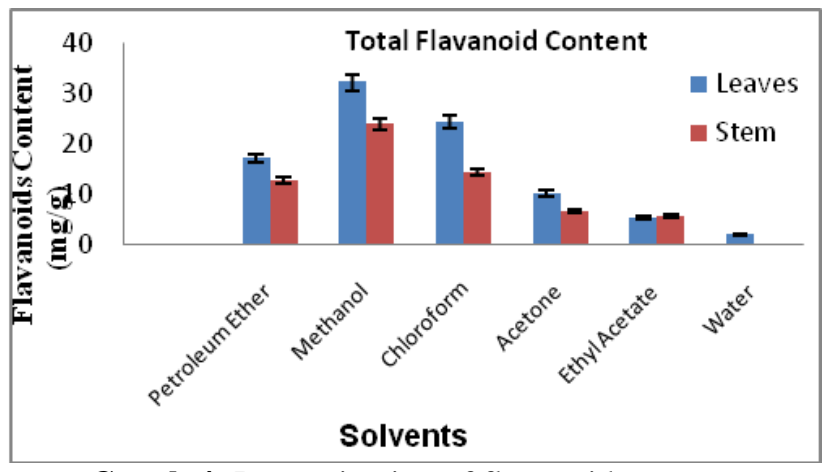

Graph 4: Determination of flavonoids content 


\section{International Journal of Science and Research (IJSR) \\ ISSN (Online): 2319-7064}

Index Copernicus Value (2013): 6.14 | Impact Factor (2015): 6.391

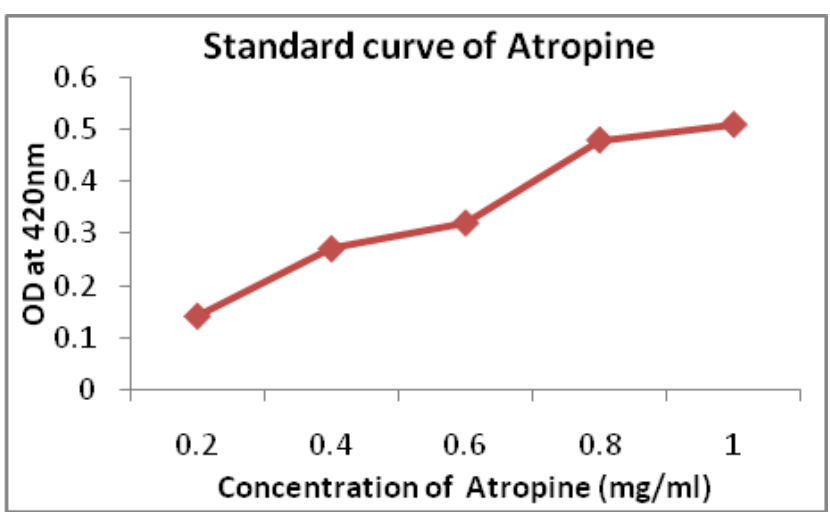

Graph 5: Standard curve of Atropine

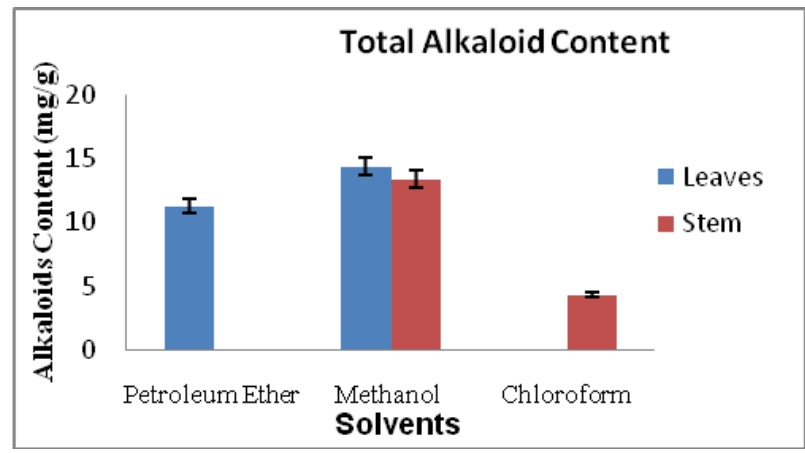

Graph 6: Determination of Alkaloids

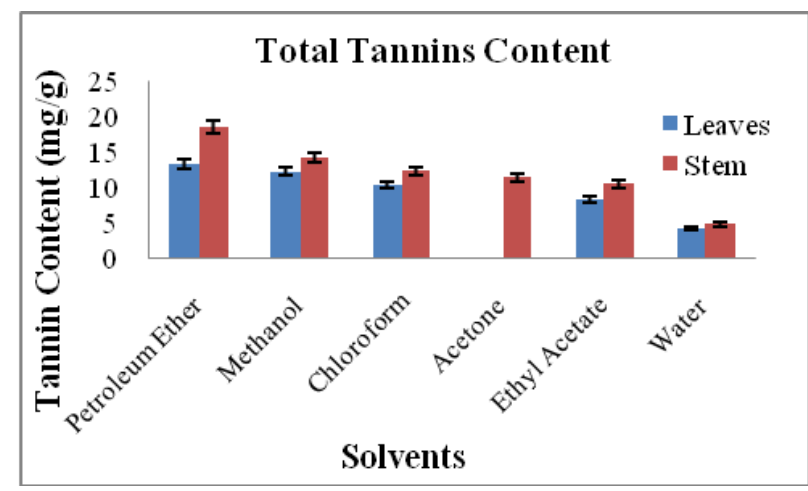

Graph 7: Standard curve of Tannic acid.

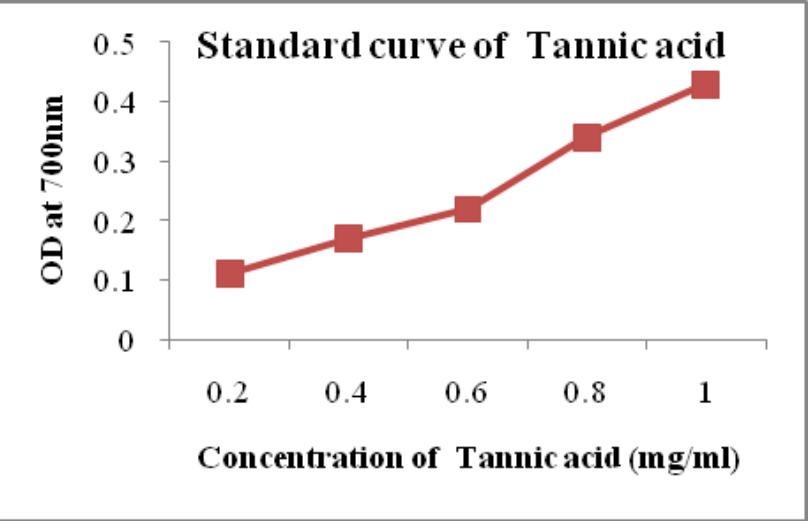

Graph 8: Detemination of tannin content

\section{References}

[1] Biju John, VRK Reddy, Sulaiman C T.. Total Phenolics and Flavonoids in Selected Justicia Species. Journal of Pharmacognosy and Phytochemistry Vol. 2 (4) (2013) Pp: 51-52.
[2] Jayaraman J. Laboratory Manual in Biochemistry New Delhi: Wiley Eastern Limited, New Delhi. (1981).

[3] Kirtikar KR, Basu BD., Indian Medicinal Plants. Vol.1, International book distributors, Dehardun, India, (1995) pp.830-832.

[4] Yoirentomba, M. S., and G. A. Shantibala Devi., Seasonal variation of bioactive alkaloids content in Aconitum spp. from Manipur, India. Bio Scan. (2011) $6: 439-442$.

Volume 5 Issue 6, June 2016 www.ijsr.net 